\title{
The Political Economy of Designing Bilateral Investment Treaties
}

\author{
Jiayi Zhang \\ jzhang80@syr.edu \\ Ph.D. Student, Syracuse University
}

September 2020

Prepared for the 2020 APSA Annual Meeting and Exhibition

Please do not cite or quote.

\begin{abstract}
Bilateral investment treaties are designed and influenced by many actors and historical events. Treaties vary a lot in terms of their dispute settlement mechanisms. Each treaty has its own requirements about arbitration venues, limitations, and scopes. The variation is puzzling. Why do some bilateral investment treaties provide a high level of dispute settlement protection to investors while others do not? It has been widely debated whether bilateral investment treaties are economic agreements or political tools. Both economic and political approaches have produced some solid evidence to shed light on the proliferation of bilateral investment treaties. Yet neither of them has provided a satisfactory answer. We believe bilateral investment treaties, as a form of international treaty by nature, should have both economic and geopolitical implications, and thus a good explanation needs to address both economic and geopolitical motivations. We argue that both economic and geopolitical considerations shape states' preferences in designing dispute settlement provisions. Specifically, economic needs have positive effects while geopolitical needs have negative ones on the strength of dispute settlement provisions.
\end{abstract}


BIT

DSM

FDI

FET

FCN

FTA

GATT

ICSID

IIA

ISDS

MFN

MNC

NT

OECD

TIP

UNCITRAL

UNCTAD

WTO

\section{Abbreviations}

bilateral investment treaty

dispute settlement mechanism

foreign direct investment

fair and equitable treatment

treaty of friendship, commerce and navigation

free trade agreement

General Agreement on Tariffs and Trade

International Centre for Settlement of Investment

Disputes

international investment agreement

investor-state dispute settlement

most favored nation

multinational corporation

national treatment

Organisation for Economic Co-operation and

Development

Treaties with Investment Provision

United Nations Commission On International Trade Law

United Nations Conference on Trade and Development

World Trade Organization 


\section{Introduction}

Foreign direct investment (FDI) can create a win-win situation for both source and host countries ${ }^{1}$. However, governing international investment is very puzzling to many observers, since the international investment regime differs substantially from other international institutions. Scholars have identified three unique features of the international investment regime. First, it is highly decentralized since it is neither based on a comprehensive global investment constitution (Pauwelyn 2014), nor regulated by an international organization comparable to the General Agreement on Tariffs and Trade (GATT), or the World Trade Organization (WTO) (Simmons 2014). Instead, states have negotiated 2,958 bilateral investment treaties (BITs) and 382 Treaties with Investment Provisions (TIPs) (UNCTAD 2018) with each other to promote and protect foreign investment. ${ }^{2}$. Second, BITs are highly controversial because they give investors a privileged status (Pauwelyn 2014; Simmons 2014). International law scholars have studied many important elements in BITs. One type of them is Standards of Treatment, which are substantive rules of protecting and promoting investment. Examples could be provisions related to national treatment (NT), most-favored-nation treatment (MFN), fair and equitable treatment (FET), expropriation, transfer of funds, umbrella cause, etc. The

\footnotetext{
${ }^{1}$ The terms "source country/ home country/ capital exporting country" and "host country/capital importing country" simply reflect the direction of FDI. In general, the former refers to developed/North/Western countries, while the latter tends to be developing/ South/ non-western countries. However, more BITs signed between two developing countries, along with more FDI flows from developing countries, have cast doubt on this argument

${ }^{2}$ BITs replaced the old-fashioned friendship, commerce, and navigation treaties (FCN Treaties). The US government has signed many FCN treaties in the post-World War II era with more than twenty countries. FCN treaties tend to address a wide range of issues, including human rights, trade, investment protection, intellectual property, taxation, immigration, and so on; the roles of FCN treaties have been replaced by specific international treaties like BITs, the GATT, and the International Covenant on Civil and Political Rights (Coyle 2012).
} 
other type of BIT elements is the dispute settlement mechanism (DSM), especially the controversial Investor-State Dispute Settlement (ISDS), which is the first, and by far the only international regime in which non-state actors have direct standing against host state governments without exhausting local remedies (Bonnitcha, Poulsen, and Waibel 2017). Investors often take advantage of this privilege, as the number of arbitration cases brought against host states by investors at the International Center for Settlement of Investment Disputes (ICSID) has grown steadily (Berge 2018). Third, the development of international investment law is organic. As Pauwelyn (2014: 404) point out, the whole system emerged through evolution, not revolution, and was designed and influenced by actors like states, arbitrators, and scholars, as well as historical events like decolonization, the end of cold war, and financial crisis. This evolution doubtlessly has an impact on treaty design. Although almost all BITs contain Standards of Treatment and DSM, the former type is fairly standard across treaties while the latter one varies a lot (Allee and Peinhardt 2010, 2014). Each BIT has its own requirements about DSM fora (arbitration venues), as well as limitations and exceptions to the scope of DSM. The variation in DSM of BITs is puzzling and worth studying because it is not only a legal issue, but also has important political implications. From a legal perspective, it can gauge the efficacy of a treaty, since Standards of Treatment are pretty standard across treaties. From a political perspective, the design of DSM provisions has a strong impact on how future disputes between investors and host countries will be resolved.

The unique features of the international law regime, which is mainly composed of BITs, have important political implications for researchers, government officials, and investors. Why do countries sign BITs, even at the expenses of limiting their own 
sovereignty? Why do some BITs provide high level of DSM protection to investors while others do not? In this paper, we seek to answer these questions by using quantitative methods. We argue that both economic and political considerations shape states' preferences in designing DSM provisions. Specifically, economic needs have positive effects while geopolitical needs have negative ones on the strength of DSM. When the geopolitical needs are large, the positive effects of economic needs will decrease.

This paper is organized as follows. The second part examines existing explanations for the proliferation of BITs and variations in treaty design. In the third part, we provide a theoretical discussion and derives testable implications._This will be followed by a discussion on research design in Section IV. In section V, we display and discuss our statistical findings. The last part concludes this research and discuss the plausible contributions of the project to the broader discussion on governing international investment.

\section{Literature Review}

Why do states adopt BITs? What explains the variation in DSM provisions of BITs? A burgeoning literature attempts to explain the proliferation of BITs. The first strand of the literature focuses on economic explanations, which assumes that countries sign BITs after bargaining and negotiation and highlights the economic role of BITs in protecting and promoting foreign investments. Another strand of the literature focuses on the political side of the story. From this perspective, the main reason for countries to sign BITs is to promote political and diplomatic agendas instead of protecting and promoting 
foreign investment. Table 1 provides a summary of the literature review, in which the highlighted parts represent the potential contributions of this project.

\subsection{Economic Explanations}

Economic explanations on BIT adoption and DSM design tend to focus on either

host or home states.

\section{Table 1. Summary of Literature Review}

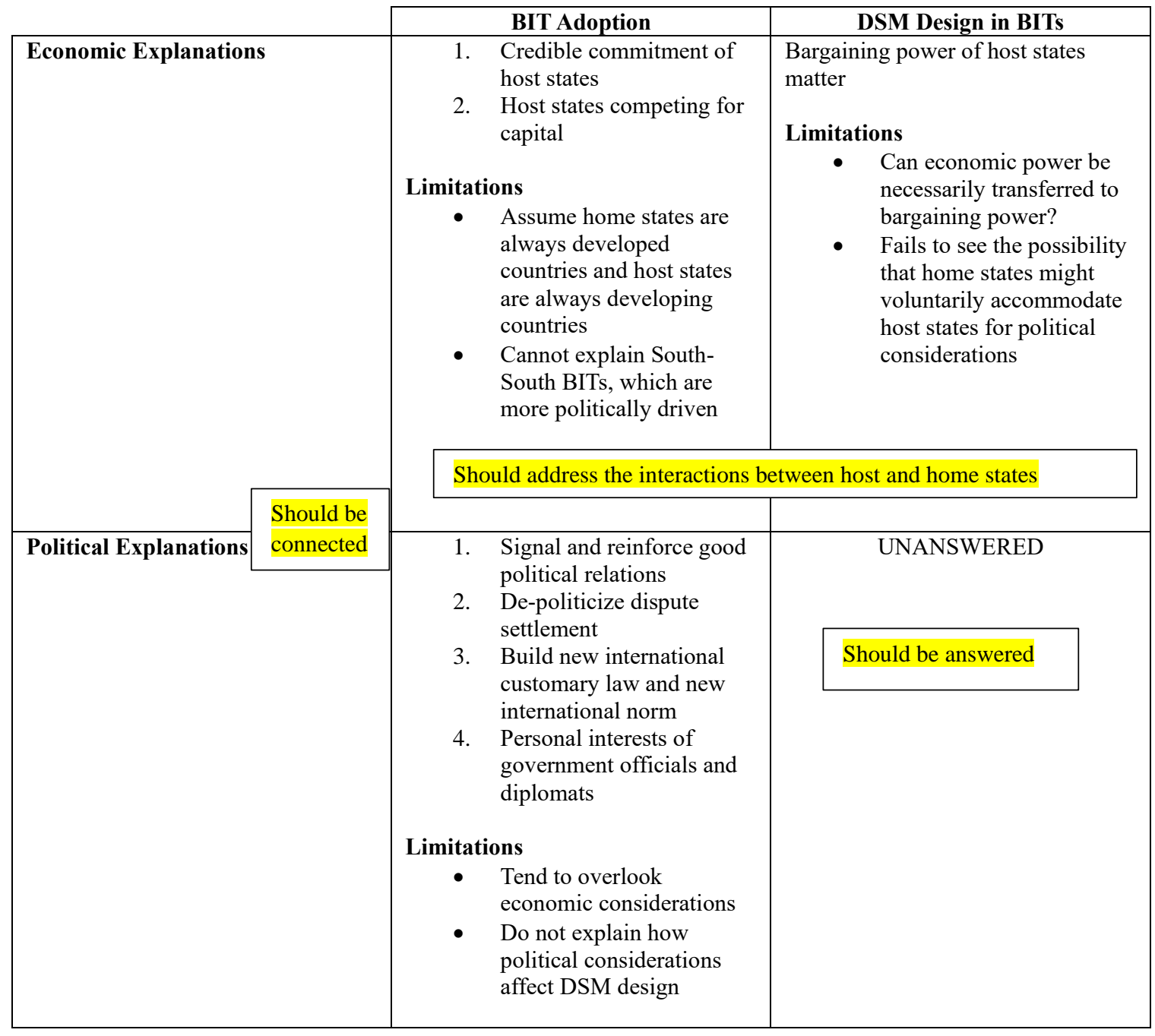

\subsubsection{BIT Adoption}


Two economic mechanisms work here, and both of them focus exclusively on host states. First, host states use BITs to ensure investors from home states. Since most host states have poor legal institutions, investment treaties can be used as a credible ex post commitment for host states to have their hands tied (Fearon 1997). BITs solve the problem of underprovision of investment by voluntarily increasing host countries' ex post costs (Milner 2014). Besides, host countries can also use investment treaties as an ex ante commitment to demonstrate their seriousness of protecting foreign investment (Neumeyer and Spess 2005; Rose-Ackermand and Tobin 2005). Second, developing countries sign BITs to compete for foreign capital (Betz and Kerner 2015; Elkins, Guzman, and Simons. 2006, Jandhyala, Henisz, and Mansfield 2011). This argument suggests that capital-importing countries (developing countries) negotiate BITs with capital-exporting countries (developed countries) in order to compete for capital, usually as a response to peer pressure. Simmons (2014) adds plausibility to this account by showing that developing countries sign more BITs when they encounter economic difficulties.

However, these pragmatic economic explanations have limitations. First, they mainly focus on host states, and tend to assume that home states are always developed countries while host states are always developing countries. Yet nowadays we cannot draw a clear boundary line as a result of a recent development in international investment. Some traditional capital importing countries, like China, Brazil, and UAE, have started investing abroad. Recent BITs signed by these countries reflect their needs to protect outward foreign investment. For example, the newest model of Chinese BITs with African countries contains some notable hallmarks of a North-South BIT, which ignore 
the sustainable development of the host country, introduce culturally inappropriate institutional mechanism for dispute resolution (Kidane and Zhu 2014), and pay little attention to local public interest, social policy goals, and wider policy objectives of host states (Ofodile 2013). Second, these studies tend to ignore a large number of BITs signed between developing countries, or in other words, South-South BITs. As Bonnitcha, Poulsen and Waibel (2017) point out, there are many "strange BITs" such as the one signed between Vietnam and Algeria, Bulgaria, and Uzbekistan in 1996. These BITs are strange because we can hardly see foreign investment in either direction. Therefore, those countries sign BITs nether because they want to show credible commitments nor because they want to compete for capital.

\subsubsection{DSM Design in BITs}

What explains the variation in DSM provisions of BITs? Under the umbrella of credibility-based explanations, some scholars go one step further and attempt to open up the "black box" of BITs and examine effects of specific treaty provisions. These studies highlight the economic role of BITs as well but put emphasis on bargaining power and economic characteristics of home states. In general, these studies assume that economically powerful countries have more bargaining power. For example, Allee and Peinhardt (2010) identify the systematic variation in legal delegation to the International Center for the Settlement of investment Disputes (ICSID), and argue that home states with strong economic power can include strong ICSID clauses in BITs while weak home governments are less likely and less capable to do so. In another paper, the same two authors (Allee and Peinhardt 2014) evaluate three explanations for BIT design: the severity of host countries' credible commitment, bargaining power of home countries, 
and rational design of international institutions to cope with future uncertainty. Their analysis suggests that the bargaining power account is the most plausible explanation. In contrast, states with weak bargaining power are more likely to have their hands tied by unfavorable BITs, especially in the provisions of investment disputes settlement (Simmons 2014). These arguments have been confirmed by Alschner and Skougarevskiy (2016)'s content analysis of over 2100 international investment treaties. Their findings reveal that developed countries tend to maintain a high level of consistency in their BITs, which indicates strong capability of rulemaking.

Although this argument looks reasonable at face value, it is questionable. As Berge and Stiansen (2016) point out, economic power cannot be necessarily transferred to leverage in negotiation since the goal of both parties is to reach a deal, not to simply compare their economic power. In order to reach a deal, the power of economic expertise should be the lynchpin. Countries with higher level of economic expertise power can gain more in the bargaining and make favorable provisions in the end. In addition, even with high level of economic power and economic expertise, host states might still not make favorable provisions due to political considerations. For instance, some studies on the formation of Chinese BITs have noticed that China is using a flexible and inconsistent approach when negotiating investment agreements. Chinese negotiators tend to use its own model that contains less stringent provisions when the partner is a developing country and accept its partner countries' BIT models and include more stringent provisions when negotiating BITs with developed countries (Chi 2017; Zeng 2015).

\subsection{Political Explanations}


There are four related arguments under this umbrella, and all of them address BIT adoption. First, BITs can be used as a costless tool to signal and reinforce friendly diplomatic relations (Bonnitcha, Poulsen and Waibel 2017), because the wording of BITs is relatively consistent and thus not much negotiation is needed (Montt 2009). Many developed (US, Canada, UK, Germany, etc) and developing countries (China, India, Malaysia, Turkey, etc.) have their own BIT models. This view partly explains why there are so many "South-South" BITs, since it is not difficult to make them.

Second, BITs can achieve de-politicization when investors and host countries have disputes. By allowing non-state actors to bring international arbitrations directly against host governments, BITs avoid the involvement of home governments, at least on paper. For developed countries, de-politicizing investment disputes can effectively prevent newly independent developing countries from getting close to the communist states in the cold war (Maurer 2013). The ICSID also considers de-politization as a major justification for BITs, which can lower the likelihood of developed countries intervening in dispute resolution and thus reduce inter-state conflicts (Bonnitcha, Poulsen, and Waibel 2017).

Third, BITs can help build new international customary law and confirm a new international norm. Some studies suggest that developed countries like the United State (Vandevelde 1988; 1992) and the United Kingdom (Poulsen 2015) believe that signing BITs would be beneficial to build customary international law. At that moment, these countries were facing large-scale expropriations of foreign investments in newly independent countries, and the challenge of developing countries threatening to abandon the Hull Doctrine at the UN General Assembly in 1960s and 1970s. Since there is no centralized international investment institution, they believe the accumulation of BITs 
will eventually create a customary law that binds all countries, even those without BITs. Likewise, as Jandhyala, Henisz, and Mansfield (2011) argue, the bulk of BITs signed by pairs of developing countries are based on a political motivation to gain legitimacy and acceptance, because those countries viewed BITs as a global standard.

Fourth, diplomats want BITs because they can use BIT negotiation as "perks" to gain travel opportunities, budgets, prestige and power (Poulsen and Aisbett 2016). Nonstate actors like bureaucrats can play a significant role in international law and governance (Abbott 2008). For example, dysfunctional international organizations rarely exit from international politics because diplomats need to utilize resources from such organizations to enrich themselves or their cronies (Gray 2015). Similarly, while negotiating BITs, bureaucrats and diplomats might make decisions that can be rational for themselves, but irrational for the country as a whole (Bonnitcha, Poulsen, and Waibel 2017).

Nevertheless, the political explanations are not flawless. First, these arguments have yet to provide a satisfactory explanation of whether countries' political motivations are consistent with their economic motivations in protecting and promoting foreign investments. When negotiating South-South BITs, do developing states really ignore any potential economic ramifications? For instance, BITs deemed as friendship symbols can trigger accidents waiting to happen, such as unexpected disputes and arbitrations. Some Latin American countries have terminated some of their BITs and withdrew from the ICSID convention (Waibel et al. 2010). Under such a circumstance, can developing countries still negotiate pure political BITs? Current answers to this question are at best mixed. Some scholars contend that due to lack of expertise and information, developing 
countries blindly believe that signing BITs can always be economically beneficial (Poulsen 2011; 2015), while other evidence suggests a new trend that more and more developing countries are making more stringent BITs (Berger et al. 2011; van Harten 2015). Second, studies focusing on political explanations do not answer the questions of how political consideration influence DSM design. They tend to employ simple dichotomous variables as their dependent variables (Allee and Peinhardt 2014), and rarely look into variations in key elements like standards of treatment and DSM.

In sum, both economic and political approaches have produced some solid evidence, both quantitatively and qualitatively, to shed light on the proliferation of BIT as well as DSM design. Yet neither of them has provided a satisfactory answer. For economic explanations, they tend to focus on characteristics of either host or home states and overlook the interactions between them. For political explanations, they tend to disconnect political considerations from economic considerations. We believe BITs, as a type of international treaty by nature, should have both economic and political implications, and thus a good explanation needs to address both economic and political motivations. In addition, a good explanation should highlight the interaction between both host and home states instead of focusing on only one side. Hence, our project aims to address this gap.

\section{Economic and Political Considerations in Designing BITs}

In this paper, we argue that both economic and geopolitical considerations shape the strength of DSM in BITs. Specifically, we argue that economic considerations increase 
the level of stringency in BITs while geopolitical considerations reduce it. Furthermore, when geopolitical incentives between two countries are large, the positive effects of economic considerations on the strength of BITs will go down, compared to the situation when geopolitical incentives are low.

We define economic considerations of two countries as the investment potential between them. Investment potential has a positive effect on DSM strength, because when the investment potential between two countries are large, investments are more likely to happen, and the likelihood of investment disputes will go up. Hence, investors would advocate for strong DSM provisions to protect their potential investments.

We define geopolitical considerations of BIT-making countries as the incentive to maintain the importance (Chilton 2016) or closeness (Zeng 2016) of political relations between them. The logic of the negative effect of geopolitical considerations on the strength of DSM is that states with good diplomatic relations do not wish to escalate disputes and tend to avoid aggressive DSM and seek to solve the problems informally. For example, the Chinese government provides its state-owned enterprises with implicit insurance or state bailout to encourage them to invest in "risky" countries with poor legal institutions (Shi 2015). When Chinese investors have disputes with host governments, they rely on channels that they know, value and trust, like diplomatic intervention by the Chinese government (Li and Liang 2012). Therefore, when states negotiate BITs with countries that are important or close to them, they would prefer less stringent DSM provisions.

Investors, home government, and host government are key actors in treaty design. This is determined by the nature of DSM. Investors and host government are key actors 
because DSMs in BITs, especially ISDS, allow investors to bring international arbitrations directly against host government. Home government is also an important actor because it negotiates BIT provisions with host government. When governments negotiate BITs, they would first think of the investment potentials between the two countries because a BIT is by nature an economic agreement. Then they will consider the geopolitical needs, since BITs can be easily negotiated as diplomatic symbols (Poulsen,2015; Poulsen and Aisbett,2016; Chilton 2016). There could be four possible scenarios. Table 2 summarizes key actors and their preferences in different scenarios.

Table 2. Actors and their preferences

\begin{tabular}{|c|c|c|c|}
\hline & \multicolumn{2}{|c|}{ Home Side } & \multirow{2}{*}{$\begin{array}{c}\text { Host Side } \\
\text { Host Government }\end{array}$} \\
\hline & Investors & Home Government & \\
\hline $\begin{array}{l}\text { Scenario } 1 \\
\text { High investment } \\
\text { potentials and low } \\
\text { geopolitical needs }\end{array}$ & More Stringent DSM & More Stringent DSM & More Stringent DSM \\
\hline $\begin{array}{l}\text { Scenario } 2 \\
\text { High investment } \\
\text { potentials and high } \\
\text { geopolitical needs }\end{array}$ & More Stringent DSM & Less Stringent DSM & More Stringent DSM \\
\hline $\begin{array}{l}\text { Scenario } 3 \\
\text { Low investment } \\
\text { potentials and high } \\
\text { geopolitical needs }\end{array}$ & Do not care & Less Stringent DSM & Less Stringent DSM \\
\hline $\begin{array}{l}\text { Scenario } 4 \\
\text { Low investment } \\
\text { potentials and low } \\
\text { geopolitical needs }\end{array}$ & & $\begin{array}{l}\text { Boilerplate Agreements } \\
\text { (very unlikely) }\end{array}$ & \\
\hline
\end{tabular}

When the investment potentials are high and there are low geopolitical needs, the design of BITs will be determined mostly by the powerful home side where investors come from, regardless of domestic institution quality of host states (Allee and Peinhardt 2014). In other words, investors and home government have considerable bargaining leverage over host government. This situation can be illuminated by existing economic explanations that highlight host states "tying their hands" to show credibility, or home 
states having strong bargaining power. Investors from home states are very concerned about potential huge ex post sunk costs if their properties got expropriated by home governments after establishing investments. Therefore, they would contribute to BIT negotiations by suggesting more investor-friendly DSM provisions. Home government would also prefer stronger DSM to protect investors, since there are no political incentives to make concessions. In contrast, in order to attract investments, host government will choose to accommodate home government and investors.

When both investment potentials and geopolitical needs are high, the interests of investors and host government remain the same because the former is still concerned about potential huge sunk cost while the latter still wants to attract more investments. However, since home government wants to maintain a good relationship with host government, it would take into consideration both the interests of investors and the diplomatic relation between the two countries. Therefore, home government would deliberately limit their bargaining power to accommodate host government at the international level, which in fact will empower host government. In other words, protection by DSM provisions would be at the intermediate level.

When the economic needs are not strong, bargaining power and expertise would not play important roles in the bargaining. Actually, bargaining itself is not that important because the symbolic role of a BIT outweighs its economic role. In the case, investors would not be very interested in participating in the negotiation since they are not going to invest. However, both home and host governments want a BIT being made as soon as possible to produce a positive diplomatic outcome, and hence they do not care about the 
strength of protection since they do not expect investors would take advantage of the treaty. As a result, DSM provisions in such BITs will have protection at a low level.

The fourth scenario is a rare one and is very unlikely to happen in the real world. When both economic and geopolitical needs are low, states might want to sign a BIT just to look good or as "photo-ops". They might just use previous treaty as a template and sign new treaties with a number of other countries (Minhas 2016). In this situation, the strength of DSM provisions varies because they are produced by “copy and paste", without seriously negotiating the details.

\section{Research Design}

In this study, we use a dataset compiled by the International Investment Agreements (IIA) Mapping Project, which was crawled from the website of the United Nations Conference on Trade and Development (UNCTAD) with Python 3. This dataset contains 2479 BITs signed by 183 country/region pairs between 1959 and 2016. The IIA Mapping Project is a collaboration between the UNCTAD and universities across the world. Law scholars and students from these universities map and identify contents of BITs in order to understand trends in treaty design and differences in policy preferences. Mapped treaty elements include definitions, standards of treatment, DSM, institutional issues, treaty duration, and so $\mathrm{on}^{3}$.

\footnotetext{
${ }^{3}$ For detailed information about how treaty elements are mapped, please read Mapping Project Description \& Methodology, available at https://investmentpolicyhub.unctad.org/Upload/Documents/Mapping\%20Project\%20Description\%20and\% 20Methodology.pdf, accessed 12/01/2018
} 
Zhang

\section{Dependent Variables}

In order to study the variations in DSM provisions in BITs, we use 12 specific treaty provisions to create two indices to measure the strength of DSM, following the coding strategy presented by Frenkel and Walter (2017). These two indices are two count variables that will be used as dependent variables. Table 3 provides a summary of the provisions and the assigned values. 
Table 3. Overview of DSM Provisions in BITs

\begin{tabular}{ll}
\hline Provision Type (Assigned value) & Frequency \\
\hline Fora of Arbitration-Number of Fora Index & \\
ICSID (1) & 2,168 \\
UNCITRAL (1) & 1,622 \\
Other (1) & 861 \\
Domestic courts of host states (1) & 1,604 \\
DSM Limitations and Restrictions Index & \\
Scope of Claims & 654 \\
Covers only treaty claims (0) & 1,824 \\
Covers any dispute connected to investment (1) & 73 \\
Lists specific bases of claim beyond treaty (0.5) & \\
Limitation of Provisions Subject to ISDS & 2,356 \\
All provisions are subject to ISDS (1) & 195 \\
Treaty limits the scope of provisions (0) & \\
Exclusion of Policy Areas from ISDS & 69 \\
Excludes policy area from ISDS (0) & 2,481 \\
Does not exclude policy area from ISDS (1) & \\
Consent to Arbitration & 98 \\
Consent on a case-by-case basis (0) & 2,313 \\
Provides prior consent (1) & 1,591 \\
Relationship between ISDS Fora & 211 \\
Fork in the road/No U turn (0) & 749 \\
Primacy of local courts (0.5) & \\
No reference (1) & 180 \\
Limitation Period for Submission of Claims & 2,369 \\
Limited time period (0) & 94 \\
No limitation (1) & 2,455 \\
Provisional Measures & 112 \\
Allows for provisional or interim measures (1) & 2,435 \\
Does not allow for provisional or interim measures (0) & \\
Limited Remedies & \\
Limited available remedies (0) & \\
No limitation on available remedies (1) & \\
\hline Adapted from Frak and & \\
\hline
\end{tabular}

Note: Adapted from Frenkel and Walter (2017). Data updated.

The first index captures the number of fora specified in BITs for future dispute settlement. A BIT usually lists several international or domestic arbitration fora, ranging from standing organizations like ICSID, ad hoc arbitration venues like the United Nations Commission on International Trade Law (UNCITRAL), regional arbitrations centers like 
the ones in New York ${ }^{4}$, Singapore ${ }^{5}$, and Hong Kong ${ }^{6}$, to domestic courts, and alternatives to arbitration. The higher the number of DSM fora, the more options investors will have, and thus the stronger the DSM will be, all else being equal.

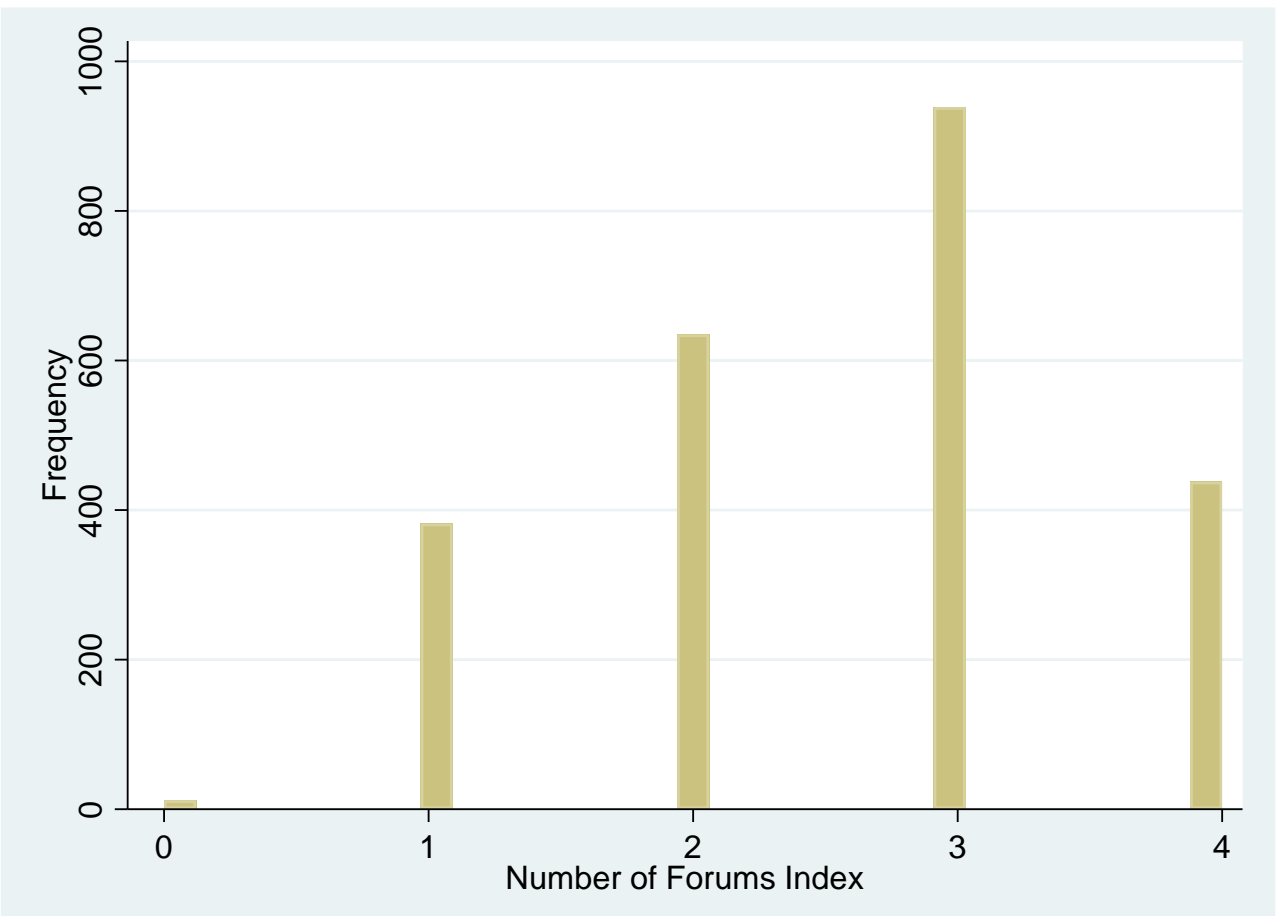

Figure 1. Number of Fora Index Score

The second index measures the limitations and restrictions of DSM, which includes two aspects: scope and consent, and relationship between fora. Scope and consent variables indicate some requirements for bringing arbitrations to fora.

Specifically, those provisions could specify what type of claims can be made (scope of claims), what provisions can be used for ISDS (limitation of provisions subject to ISDS), what policy areas could be excluded (Exclusion of policy areas from ISDS), and whether

\footnotetext{
${ }^{4}$ New York International Arbitration Center, see https://nyiac.org/ for more information.

${ }^{5}$ Singapore International Arbitration Centre, see http://www.siac.org.sg/ for more information.

${ }^{6}$ Hong Kong International Arbitration Centre, see http://www.hkiac.org/ for more information.
} 
consent to arbitration has to be given on a case-by-case basis (Consent to arbitration).

Clauses about relationship between fora set rules to reduce forum shopping. For instance, a "fork in the road" clause suggests that investors have to choose only one forum from all available options, and a "no U turn" clause means that once investors raise a claim at an international forum, they cannot go back to domestic courts. Either "fork in the road", or "no U turn" clauses, poses some restrictions on choosing dispute settlements, and thus is assigned a value of 0 , while BITs contain no such clauses are given a value of 1 . The DSM limitations and restrictions index will be the combination of scope and consent, and relationship between fora variables. A higher value of this index indicates stronger DSM, ceteris paribus.

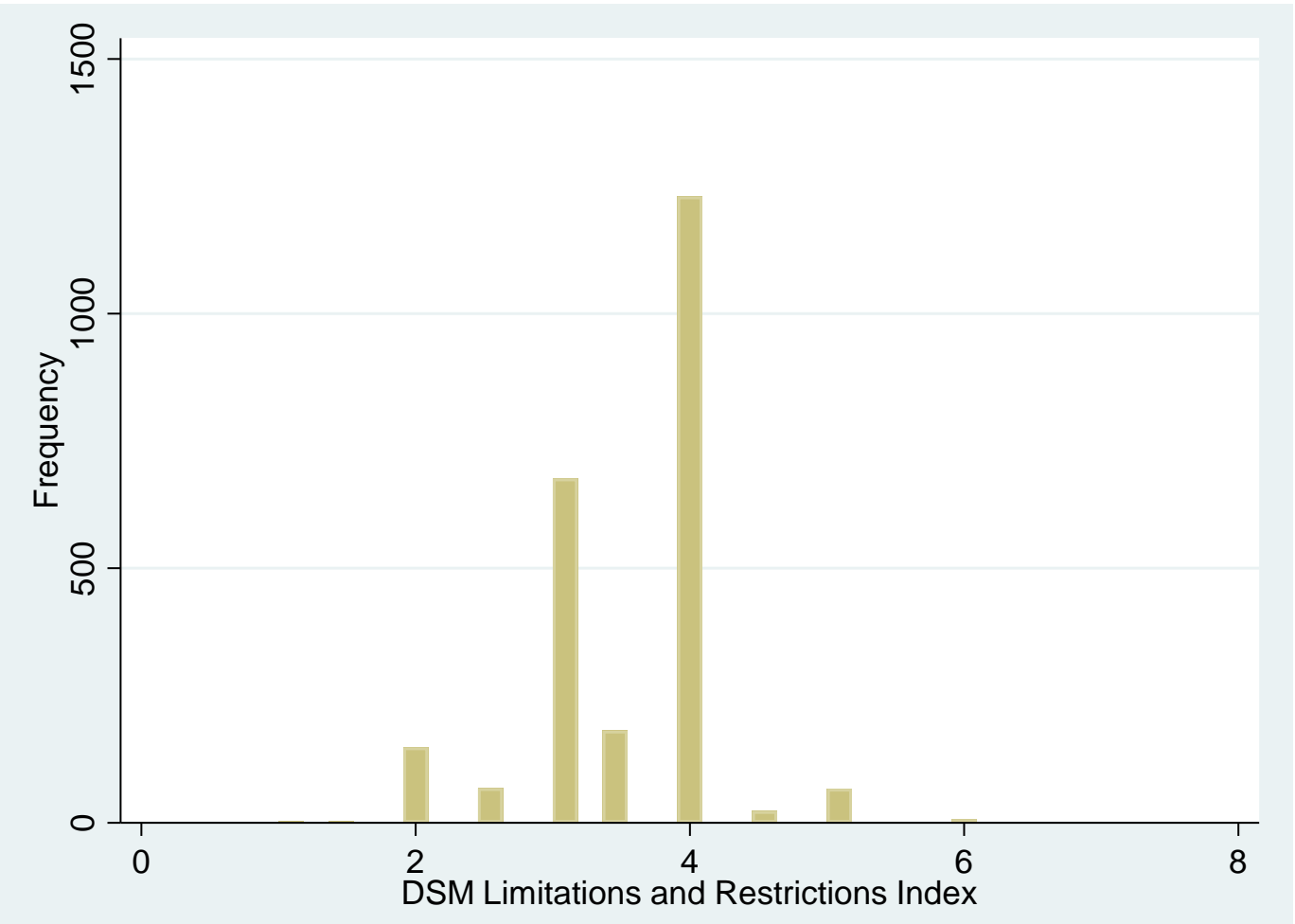

Figure 2. DSM Limitations and Restrictions Index Score 
Zhang

\section{Independent Variables}

There are two independent variables proposed: geopolitical alignment and economic investment potentials. To measure the investment potentials of treaty parties, we refer to Allee and Todd (2014: 61)'s rules in determining which treaty party is host state $\left.^{7}: 1\right)$ if a state's aggregate GDP is less than one-fifth that of the other, then they have high investment potentials; or 2) if a BIT is signed between an OECD (Organisation for Economic Co-Operation and Development) member and a non-OECD member, then the two states have high investment potentials; or 3) if the GDP per capita values of the two states differ by more than one-third, then the two states have high investment potentials. We assign a value of 1 to each high investment potentials, and a value of 0 to anything else. The figure below visualizes this operationalization.

\footnotetext{
${ }^{7}$ We are not differentiating host/home states in my research.
} 


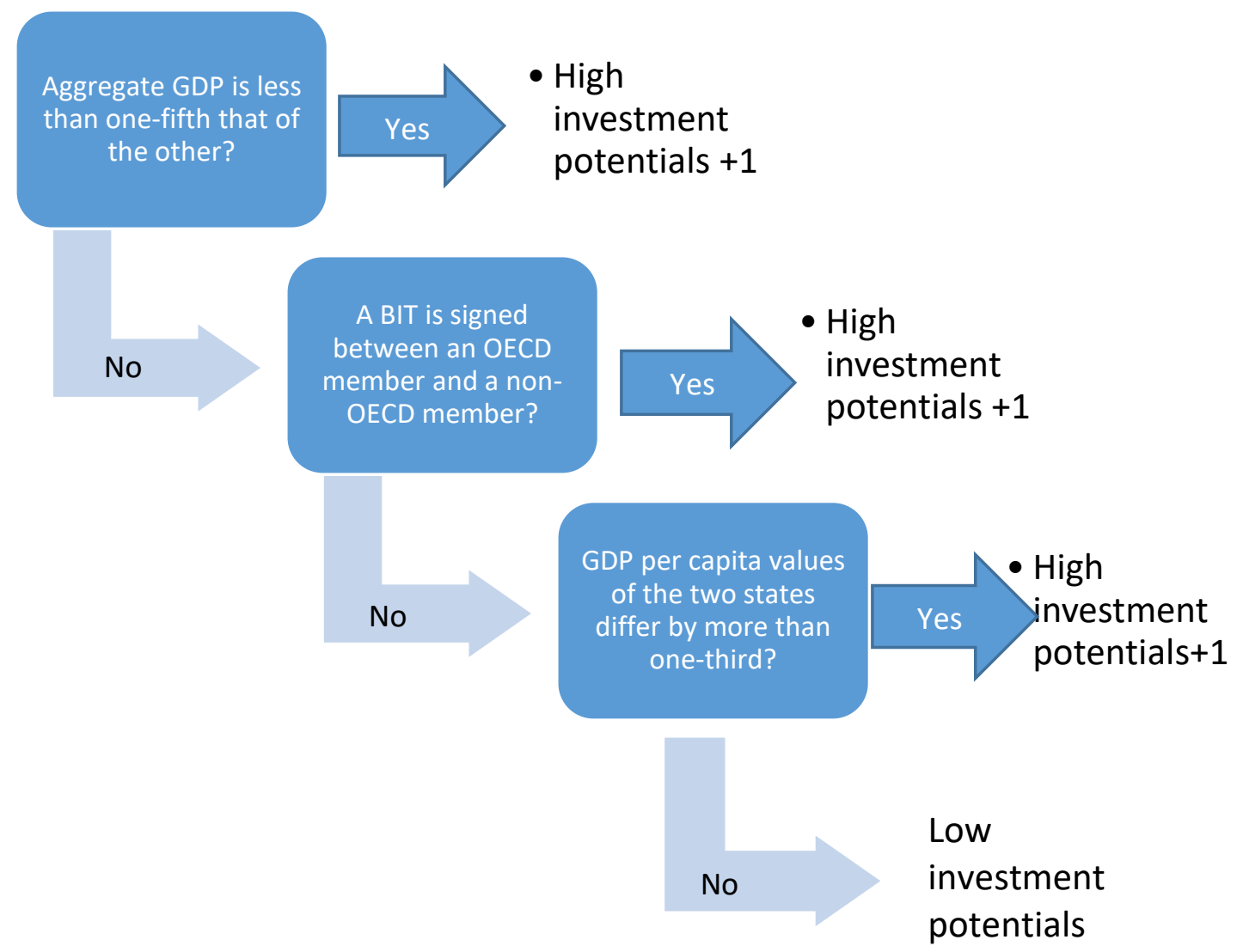

Figure 3. Measuring investment potentials between two states

To measure geopolitical alignment, we create a geopolitical dissimilarity index using the United Nations General Assembly Voting Data (Version 18.0) ${ }^{8}$ compiled by Erik Voeten (Voeten 2013), the Polity 2 scores, and the political constraint on the executive (Marshall, Gurr, and Jaggers 2015). The dissimilarity is a sum of the absolute values of the differences between two states in each of the three variables. The UNGA Voting Data covers roll-call votes in UNGA between 1946 and 2017. Specifically, we use the dyadic affinity score, the values of which range from -1 (least similar interests) to 1 (most similar interests). Similar voting patterns indicate shared foreign policy goals.

\footnotetext{
${ }^{8}$ United Nations General Assembly Voting Data (Version 18.0), available at https://dataverse.harvard.edu/dataset.xhtml?persistentId=hdl:1902.1/12379, assessed 12/08/2018
} 
Scholars have been using UNGA voting to measure states' foreign policy preferences since the institution was established (Bailey, Strezhnev, and Voeten 2017). UNGA voting is available for all states in the international system and it covers a long period (since 1946) (Struver 2016). In addition, the inclusion of the Polity 2 scores and the executive constraints scores from the Polity IV dataset enables us to measure two other important aspects of geopolitical alignment, namely, the (dis)similarity in the level of democracy and the executive branch in each treaty dyad.

\section{Control Variables}

A few control variables will also be included in the analysis. To control for cultural similarities between two countries, we include a measure of cultural proximity from the KOF Globalisation Index (Gygli, Haelg and Sturm 2019). To control for the effects of issue linkage between trade and investment, we include the sum of trade percentage of GDP from the World Development Indicators for each treaty dyad. To control for the impact of investment flows, we include the sums of FDI inward and outward flows for each country dyad. To control for the global trend in BIT formation, we include the sum of numbers of BITs signed to date (Graham, Johnston, and Kingsley 2017). Finally, we control for the geographic distance between the two countries ${ }^{9}$.

\section{Model}

The formula below depicts the basic regression model of my analysis, in which $X$ denotes the control variables.

\footnotetext{
${ }^{9}$ Distance between country and the US (km between most populous cities), from CEPII Data, http://www.cepii.fr/cepii/en/bdd_modele/bdd.asp
} 
DSM Strength $=\alpha+\beta_{1}$ economic potential $+\beta_{2}$ geopolitical alignment $+\beta_{3}$ economic

$$
\text { potential } * \text { geopolitical alignment }+\beta_{4} X+\varepsilon
$$

\section{Results}

Table 4 Effects of geopolitical alignment and investment potential on DSM in BITs

\begin{tabular}{cccc|ccc}
\hline Dependent Variable & \multicolumn{3}{c|}{ Number of Fora } & \multicolumn{3}{c}{ DSM Limitations and Restrictions } \\
& Model 1 & Model 2 & Model 3 & Model 4 & Model 5 & Model 6 \\
\hline Geopolitical & -0.004 & & 0.015 & $-0.007 *$ & & $0.016^{*}$ \\
alignment & $(-0.883)$ & & $(1.591)$ & $(-1.706)$ & & $(1.745)$ \\
Investment potential & & 0.007 & 0.092 & & -0.025 & 0.060 \\
& & $(0.145)$ & $(1.366)$ & & $(-0.567)$ & $(0.928)$ \\
Geopolitical*Potential & & & $-0.009 * *$ & & & $-0.011^{* * *}$ \\
& & & $(-2.153)$ & & & $(-2.715)$ \\
Cultural similarity & $0.003^{* *}$ & 0.002 & $0.003^{* *}$ & $0.003^{* *}$ & 0.001 & $0.004 * *$ \\
& $(2.168)$ & $(1.077)$ & $(1.998)$ & $(2.029)$ & $(0.912)$ & $(2.408)$ \\
Distance & 0.000 & 0.000 & 0.000 & 0.000 & -0.000 & 0.000 \\
& $(1.361)$ & $(0.590)$ & $(1.328)$ & $(0.014)$ & $(-0.592)$ & $(0.066)$ \\
Sum of FDI Inflow & -0.001 & -0.004 & 0.001 & 0.007 & 0.001 & 0.008 \\
& $(-0.067)$ & $(-0.735)$ & $(0.081)$ & $(0.855)$ & $(0.237)$ & $(1.003)$ \\
Sum of FDI Outflow & 0.007 & 0.009 & 0.006 & -0.002 & 0.004 & -0.003 \\
& $(0.775)$ & $(1.564)$ & $(0.635)$ & $(-0.233)$ & $(0.706)$ & $(-0.330)$ \\
Trade & 0.001 & $0.001 *$ & 0.000 & 0.000 & 0.001 & -0.000 \\
& $(0.879)$ & $(1.751)$ & $(0.707)$ & $(0.386)$ & $(0.925)$ & $(-0.039)$ \\
Numbers of BITs & 0.002 & $0.003 * *$ & 0.003 & $0.004 * *$ & $0.004 * * *$ & $0.004 * *$ \\
signed to date & $(1.379)$ & $(2.058)$ & $(1.429)$ & $(2.163)$ & $(2.861)$ & $(2.301)$ \\
\hline $\mathrm{N}$ & 743 & 879 & 743 & 743 & 879 & 743 \\
\hline
\end{tabular}

The numbers in parentheses are standard errors. ${ }^{* * *} p<=0.01 ; * * p<=0.05 ;{ }^{*} p<=0.1$

Table 4 presents the results of our empirical analysis. In Models 1 to 3, the dependent variables are the cumulative number of arbitration fora specified in a certain BIT. Neither geopolitical dissimilarity nor investment potential have statistically significant effects on the number of arbitration venues, but the coefficients of investment potential are positive. In Model 3, we introduce the interaction between geopolitical dissimilarity and investment potential, and this term has a significant negative effect on 
DSM limitations and restrictions at the $95 \%$ confidence level. This suggest that when deciding where to go for arbitration, states do take their geopolitical interests into consideration.

In Models 4 to 6, we operationalize the dependent variables as the index of DSM limitations and restrictions. Like Models 1 to 3, investment potential alone does not have statistically significant effect on the stringency of DSM clauses. In Model 4, the measure of geopolitical alignment has a negative effect at the level of $90 \%$, but its coefficient turns positive when the model also contains investment potential and the interaction term. In Model 6, the increase of geopolitical dissimilarity has a positive impact on DSM limitations and restrictions while the coefficient of the interaction term is negative and statistically significant at the $99 \%$ level, which indicates that countries tend to reduce DSM limitations and restrictions with partners whose geopolitical interests are more favorable.

Regarding control variables, we can see that the coefficients of cultural similarity are positive across all models and are statistically significant in four out of six models. This finding reveals the fact that companies prefer to invest in countries with similar cultural backgrounds and they demand more stringent DSM to protect their investments. In addition, the numbers of BITs have positive effects in all models, and the effects are statistically significant when the dependent variable is DSM limitations and restrictions. The increase in numbers resonates with the update of BIT clauses since the more BITs a state signs, the more experience of negotiation and dispute resolution it will have. 
Zhang

\section{Conclusion}

This research unites the economic explanations and the political explanations about why states sign BITs and how they design DSM provisions in BITs by suggesting an interaction-based explanation. We believe this study can contribute to the literature that suggests broader foreign policy goals often drive international economic integration (Gowa and Mansfield 1993). This project may shed lights on some new developments in international investment, such as treaty renegotiation (Haftel and Thompson 2018) and increasing arbitrations against developed countries (Berge 2018). 


\section{References}

Abbott, Kenneth W. 2008. "Enriching Rational Choice Institutionalism for the Study of International Law." U.Ill.L.Rev.: 5.

Allee, Todd and Clint Peinhardt. 2010. "Delegating Differences: Bilateral Investment Treaties and Bargaining Over Dispute Resolution Provisions." International Studies Quarterly 54 (1): 1-26.

_. 2014. "Evaluating Three Explanations for the Design of Bilateral Investment Treaties." World Politics 66 (1): 47-87.

Alschner, Wolfgang and Dmitriy Skougarevskiy. 2016. "Mapping the Universe of International Investment Agreements." Journal of International Economic Law 19 (3): 561-588.

Bailey, Michael A., Anton Strezhnev, and Erik Voeten. 2017. "Estimating Dynamic State Preferences from United Nations Voting Data." Journal of Conflict

Resolution 61 (2): 430-456.

Bennett, Andrew and Alexander L. George. 2005. "Case Studies and Theory Development in the Social Sciences." Cambridge, Mass.

Berge, Tarald Laudal. 2018. "Dispute by Design? Legalisation, Backlash and the Drafting of Investment Agreements." .

Berge, Tarald and Øyvind Stiansen. 2016. "Negotiating BITs with Models. the Power of Expertise." .

Berger, Axel and Max Büge. "Determinants of International Investment Agreements: The Case of China." .

Berger, Axel, Matthias Busse, Peter Nunnenkamp, and Martin Roy. 2011. "More Stringent BITs, Less Ambiguous Effects on FDI? Not a Bit!" Economics Letters 112 (3): 270-272.

Betz, Timm and Andrew Kerner. 2016. "The Influence of Interest: Real US Interest Rates and Bilateral Investment Treaties." The Review of International Organizations 11 (4): 419-448.

Bonnitcha, Jonathan, Lauge N. Skovgaard Poulsen, and Michael Waibel. 2017. The Political Economy of the Investment Treaty Regime Oxford University Press.

Chi, Manjiao. 2017. "From Europeanization Toward Americanization: The Shift of China's Dichotomic Investment Treaty-Making Strategy." Canadian Foreign Policy Journal 23 (2): 158-170.

Chilton, Adam S. 2016. "The Political Motivations of the United States' Bilateral Investment Treaty Program." Review of International Political Economy 23 (4): 614642. 
Chinese Embassy. 2018. "China and Uzbekistan: Good Neighbors, Good Friends, Good Partners - New Starting Point, New Opportunities, New

Journey.", http://uz.chineseembassy.org/chn/zwgx/zwgxjj/.

Coyle, John F. 2012. "The Treaty of Friendship, Commerce and Navigation in the Modern Era." Colum.J.Transnat'L L. 51: 302.

Elkins, Zachary, Andrew T. Guzman, and Beth A. Simmons. 2006. "Competing for Capital: The Diffusion of Bilateral Investment Treaties, 1960-2000." International Organization 60 (4): 811-846.

Fearon, James D. 1997. "Signaling Foreign Policy Interests: Tying Hands Versus Sinking Costs." Journal of Conflict Resolution 41 (1): 68-90.

Gallagher, Norah and Wenhua Shan. 2009. Chinese Investment Treaties: Policies and Practice. Vol. 99 Oxford University Press Oxford.

Gowa, Joanne and Edward D. Mansfield. 1993. "Power Politics and International Trade." American Political Science Review 87 (2): 408-420.

Graham, B.A., Johnston, N.P. and Kingsley, A.F., 2018. Even Constrained Governments Take: The Domestic Politics of Transfer and Expropriation Risks. Journal of Conflict Resolution, 62(8), pp.1784-1813.

Gray, Julia. 2015. "The Patronage Function of Dysfunctional International Organizations." Unpublished Manuscript.University of Pennsylvania.Google Scholar.

Gygli, S., Haelg, F., Potrafke, N. and Sturm, J.E., 2019. The KOF globalisation index-revisited. The Review of International Organizations, pp.1-32.

Haftel, Yoram Z. and Alexander Thompson. 2018. "When do States Renegotiate Investment Agreements? the Impact of Arbitration." The Review of International Organizations 13 (1): 25-48.

Jandhyala, Srividya, Witold J. Henisz, and Edward D. Mansfield. 2011. "Three Waves of BITs: The Global Diffusion of Foreign Investment Policy." Journal of Conflict Resolution 55 (6): 1047-1073.

Kidane, Won and Weidong Zhu. 2013. "China-Africa Investment Treaties: Old Rules, New Challenges." Fordham Int'L LJ 37: 1035.

Li, Quan and Liang, Guoyong, Political Relations and Chinese Outbound Direct Investment: Evidence from Firm- and Dyadic-Level Tests. 2012. Research Center for Chinese Politics and Business Working Paper No. 19. Available at SSRN: https://ssrn.com/abstract=2169805 or http://dx.doi.org/10.2139/ssrn.2169805

Mary, Hallward-Driemeier. 2003. "Do Bilateral Investment Treaties Attract Foreign Direct Investment." Only a Bit... and they could Bite.World Bank Development Research Group Policy Research Working Paper (3121).

Maurer, Noel. 2013. The Empire Trap: The Rise and Fall of US Intervention to Protect American Property Overseas, 1893-2013 Princeton University Press. 
Milner, Helen V. 2014. "Introduction: The Global Economy, FDI, and the Regime for Investment." World Politics 66 (1): 1-11.

Minhas, Shahryar Farooq. 2016. "No Title." Learning from Incredible Commitments: Evolution and Impact of Bilateral Investment Treaties.

Montt, Santiago. 2009. State Liability in Investment Treaty Arbitration: Global Constitutional and Administrative Law in the BIT Generation Bloomsbury Publishing.

Neumayer, Eric and Laura Spess. 2005. "Do Bilateral Investment Treaties Increase Foreign Direct Investment to Developing Countries?" World Development 33 (10): 1567-1585.

Ofodile, Uche Ewelukwa. 2013. "Africa-China Bilateral Investment Treaties: A Critique." Mich.J.Int'L L. 35: 131.

Pauwelyn, Joost. 2014. "At the Edge of Chaos? Foreign Investment Law as a Complex Adaptive System, how it Emerged and how it can be Reformed." Icsid Review 29 (2): 372-418.

Poulsen, L.N.S., 2011. Sacrificing sovereignty by chance: investment treaties, developing countries, and bounded rationality (Doctoral dissertation, The London School of Economics and Political Science (LSE)).

Poulsen, Lauge N. Skovgaard. 2015. Bounded Rationality and Economic Diplomacy: The Politics of Investment Treaties in Developing Countries Cambridge University Press.

Poulsen, Lauge N. Skovgaard and Emma Aisbett. 2016. "Diplomats Want Treaties: Diplomatic Agendas and Perks in the Investment Regime." Journal of International Dispute Settlement 7 (1): 72-91.

Rose-Ackerman, Susan and Jennifer Tobin. 2005. "Foreign Direct Investment and the Business Environment in Developing Countries: The Impact of Bilateral Investment Treaties." .

Simmons, Beth A. 2014. "Bargaining Over BITs, Arbitrating Awards: The Regime for Protection and Promotion of International Investment." World Politics 66 (1): 12 46.

Strüver, Georg. 2016. "What Friends are made of: Bilateral Linkages and Domestic Drivers of Foreign Policy Alignment with China." Foreign Policy Analysis 12 (2): 170-191.

UNCTAD, 2016. International investment agreements navigator.

Van Harten, Gus. 2015. "A Report on the Flawed Proposals for Investor-State Dispute Settlement (ISDS) in TTIP and CETA." .

Vandevelde, Kenneth J. 1988. "The Bilateral Investment Treaty Program of the United States." Cornell Int'L LJ 21: 201. 
L. 14: 621.

1992. "US Bilateral Investment Treaties: The Second Wave." Mich.J.Int'L

Voeten, Erik. 2013. "Data and Analyses of Voting in the United Nations General Assembly." In Routledge Handbook of International Organization, 80-92: Routledge.

Waibel, Michael. 2010. The Backlash Against Investment Arbitration: Perceptions and Reality Kluwer Law International.

Shi, W., 2015. The Political Economy of China's Outward Direct Investments (Doctoral dissertation, UC San Diego).

Wen, Xiantao, Comments on the draft of China's model BIT. Chinese Journal of International Economic Law,18 (4) (2012): 169 - 204.

Wen, Xiantao, Comments on the draft of China's model BIT (II). Chinese Journal of International Economic Law, 19 (1), (2013a):132 - 162.

Wen, Xiantao, Comments on the draft of China's model BIT (III). Chinese Journal of International Economic Law, 19 (2), (2013b):57 - 90.

Zeng, Ka. 2016. "Understanding the Institutional Variation in China's Bilateral Investment Treaties (BITs): The Complex Interplay of Domestic and International Influences." Journal of Contemporary China 25 (97): 112-129. 